\title{
Synovitis associated with serum IgM rheumatoid factor arising spontaneously in 'Old English' rabbits
}

\author{
A C HANGLOW ${ }^{1}$ C J R WELSH ${ }^{1}$ P CONN ${ }^{2}$ D S THOMAS, ${ }^{1}$ AND \\ R R A COOMBS
}

From the 'Division of Immunology, Department of Pathology, University of Cambridge; and the ${ }^{2}$ Department of Histopathology, Addenbrooke's Hospital, Cambridge

SUMmaRY This paper reports the spontaneous development of synovitis in 'Old English' rabbits concurrent with serum IgM rheumatoid factor. Female rabbits developed lesions at a higher incidence than males ( $42 \%$ compared with $17 \%)$ and the pathology was of a more severe nature. In the female rabbits synovitis was associated with concurrent high serum IgM rheumatoid factor and high serum antibody levels to Pasteurella multocida. There was no histological evidence that the joints were directly infected.

Key words: spontaneous synovitis, Pasteurella multocida.

Many groups have shown that the breed of rabbits known as 'Old English' is the most susceptible to arthritis induced by a variety of experimental procedures. For example, this breed develops the highest incidence of joint disease after serum sickness, ${ }^{1}$ intravenous injection with killed Escherichia coli, ${ }^{2}$ milk feeding (unpublished observations), and the Glynn-Dumonde model of arthritis (Hunneyball, personal communication).

In the course of our studies on experimentally induced arthritis in 'Old English' rabbits we have observed the development of joint lesions in untreated female control rabbits. Before 1981 significant joint lesions had not been observed in untreated 'Old English' rabbits. ${ }^{3}$ In 1983 the overall incidence of joint lesions arising spontaneously in both males and females was only $5 \%(1 / 20)$ but represented an incidence of $17 \%(1 / 6)$ in females. ${ }^{4}$ The incidence then began to rise over the following 18 months. No joint lesions were observed in 11 male controls over this period, but $4 / 14(29 \%)$ of female controls developed joint lesions. It was, therefore, important to establish the exact incidence of spontaneous arthritis now occurring in this breed of rabbit. Twelve female and 12 male 'Old English' rabbits were maintained for a three month period without

Accepted for publication 22 August 1985.

Correspondence to Professor $\mathbf{R}$ R A Coombs, Division of Immunology, Department of Pathology, University of Cambridge, Laboratories Block, Level 3, Addenbrooke's Hospital, Hills Road, Cambridge CB2 2QQ. any experimental manipulation. In addition, these animals were examined for any evidence of autoantibody production to either collagen or IgG rheumatoid factor (RF).

\section{Materials and methods}

R A B B I T S

Male and female 'Old English' rabbits of approximately 12 weeks of age were purchased from Cheshire Rabbit Farms Ltd (Dudden Lodge, Cheshire, UK) between February and April 1985. All rabbits received food (R14 diet-KK Greeff Ltd, Croydon, UK) and water ad libitum. The animals were subjected to no experimental manipulation other than regular bleeding from the marginal vein of the ear.

\section{ASSESSMENT OF ARTHRITIS}

Rabbits were killed by lethal administration of sodium pentabarbitone (May and Baker Ltd). Synovial fluids were recovered as previously described, ${ }^{4}$ centrifuged at $200 \mathrm{~g}$ for $15 \mathrm{~min}$ at $4^{\circ} \mathrm{C}$, and the supernatants removed and stored at $-20^{\circ} \mathrm{C}$. Synovial fluid cells were resuspended in balanced salt solution (BSS - Flow Laboratories) supplemented with $1 \%$ heat inactivated fetal calf serum (Flow Laboratories).

Enumeration of nucleated cells in synovial fluid The number of viable nucleated cells in the synovial 
fluids of rabbits was estimated with a mixture of acridine orange and ethidium bromide. ${ }^{5}$ Cells were usually more than $95 \%$ viable.

Enumeration of $T$ cells in synovial fluids

The percentage of $T$ cells in synovial fluids was determined by rosetting with papain treated rabbit erythrocytes as previously described. ${ }^{6}$

\section{Dissection of joints and histological procedures}

Both knee joints from each rabbit were dissected and the synovia divided into infrapatellar, interpatellar, and lateral synovia before fixing in $10 \%$ neutral buffered formalin and embedding in paraffin. $5 \mu \mathrm{m}$ sections were cut, stained with haematoxylin and eosin, and graded for inflammatory lesions as previously described. ${ }^{4}$

\section{Kidney histology}

Kidney samples were obtained after death, fixed in formalin, and embedded in paraffin. $3 \mu \mathrm{m}$ sections were cut and stained conventionally with haematoxylin and eosin and by the standard periodic acid silver technique.

\section{MEASUREMENT OF IgM RHEUMATOID} FACTOR

In order to overcome the problem of naturally occurring antiallotypic antibodies in rabbits, ${ }^{7}$ serum IgM RF was measured by its ability to bind to autologous heat aggregated IgG in a MrsPAH test (mixed reverse solid phase passive antiglobulin haemadherence) as previously described. ${ }^{2}$

\section{SERUM IgG ANTIBODIES TO RABBIT \\ COLLAGEN}

Rabbit sera were tested for the presence of antibodies to collagen prepared from either skin (type I) or from xiphoid cartilage (types I and II) in an enzyme linked immunosorbent assay as described by Gosslau and Barrach ${ }^{8}$ with the following modifications. The test was performed in flat bottomed microtitre plates (Dynatech Ltd) which were coated with $100 \mu \mathrm{l} /$ well of $25 \mu \mathrm{g} / \mathrm{ml}(\mathrm{mg} / \mathrm{l})$ solution of collagen dissolved in $0.1 \mathrm{M}$ acetic acid. The plates were dried in air overnight at room temperature and used immediately thereafter. A phosphate washing buffer was used containing 1\% ovalbumin (Sigma,

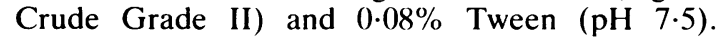
Alkaline phosphatase conjugated goat antirabbit IgG (Sigma) was used to detect rabbit IgG binding to the collagen coater plates ( $1: 250$ dilution). The amount of bound alkaline phosphatase was determined with $p$-nitrophenyl phosphate disodium (Sigma) as substrate $(1 \mathrm{~g} / \mathrm{l}$ in $0.1 \mathrm{M}$ glycine-saline buffer $\mathrm{pH} 10 \cdot 4)$. The reaction was stopped with $30 \mu \mathrm{l}$ of $3 \mathrm{M}$ sodium hydroxide. The absorbance of eac로․ sample was read at $405 \mathrm{~nm}$ in a Titerteck Multiskan? (Flow Laboratories).

MEASUREMENT OF Clq BINDING IMMUNE COM P LEXES

Immune complexes were measured in a solid phas C1q binding assay as previously described. ${ }^{9}$

MEASUREMENT OF SERUM ANTIBODIES T $\overrightarrow{0}$ $P$ multocida

Serum antibodies to $P$ multocida were measured b a MRPAH (mixed reverse passive antiglobuli® haemagglutination) assay. " $P$ multocida was iso lated from an 'Old English' rabbit that had dieç from the infection.

\section{Results}

INCIDENCE OF SPONTANEOUSLY ARISING J O IN T LESIONS

$42 \%(5 / 12)$ female 'Old English' rabbits were found. to show synovial changes in their knee joints (Table0 1). Moderate to severe lesions were detected in $3 / 19$

Table 1 Incidence of spontaneous synovitis in 'Old English' rabbits between February and June 1985

\begin{tabular}{lllll}
\hline Sex & $\begin{array}{l}\text { Incidence of } \\
\text { joint lesions }\end{array}$ & \multicolumn{2}{l}{$\begin{array}{l}\text { Incidence of moderate to } \\
\text { severe lesions }\end{array}$} \\
\cline { 2 - 5 } & No & $\%$ & No & $\%$ \\
\hline Femalc & $5 / 12$ & 42 & $3 / 12$ & 25 \\
Malc & $2 / 12$ & 17 & $1 / 12$ & 8 \\
\hline
\end{tabular}

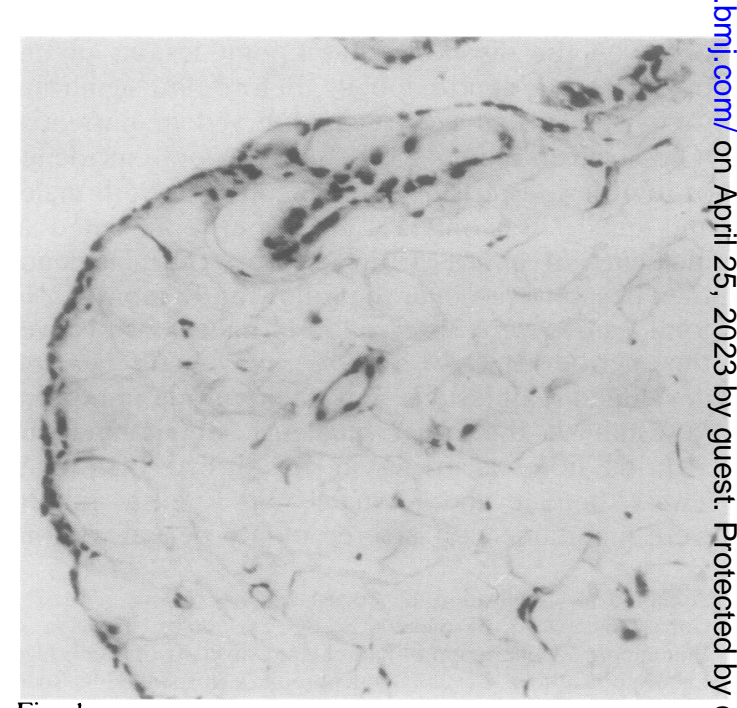

Fig. Ia 


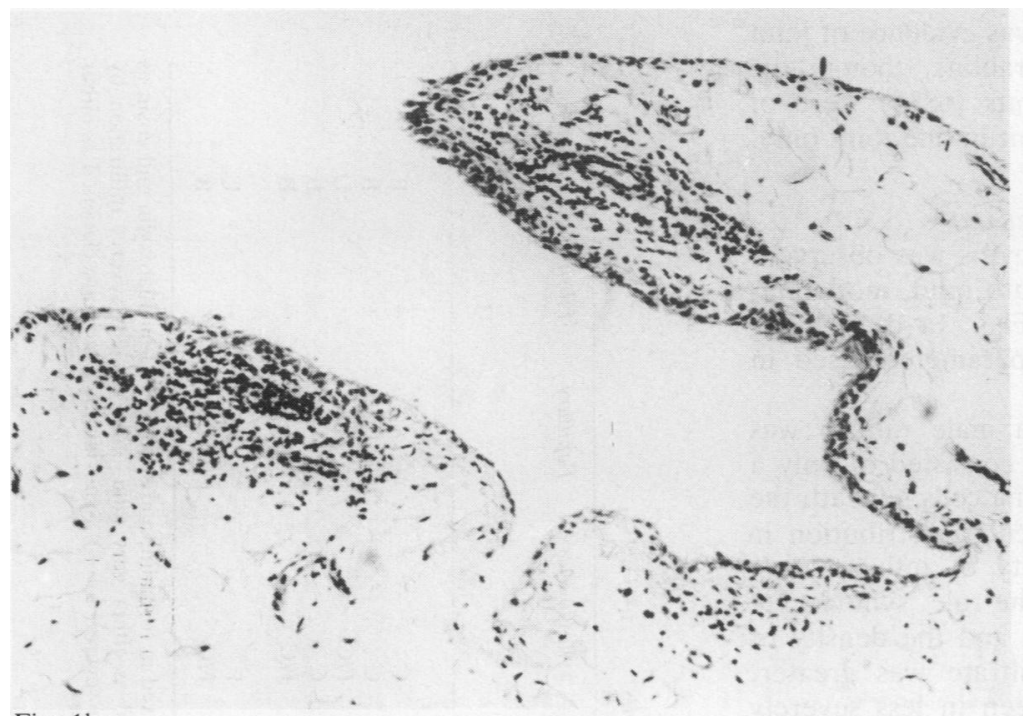

Fig. 1b

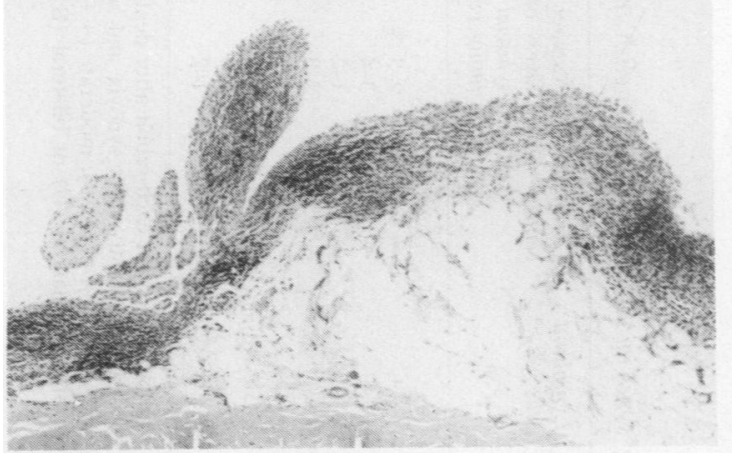

Fig. 1 Histopathology of joint lesions: (a) Normal rabbit synovium. A thin layer of flat intimal synovial cells lies on an adipose tissue stroma containing a few capillary blood vessels. Inflammatory cells are absent. (Haematoxylin and eosin, $\times 140$ ); (b) Foci of infiltration by lymphocytes and a few plasma cells. In some areas the intimal cells show cuboidal hyperplasia (rabbit 6674). (Haematoxylin and eosin, $\times 120$ ); (c) Severe inflammation in rabbit 6669. Intimal cells show cuboidal hyperplasia and multilayering There is a diffuse infiltrate of mixed chronic inflammatory cells which includes many plasma cells. (Haematoxylin and eosin, $\times 40)$; (d) High power view of moderately inflamed synovium of rabbit 6677 . Intimal cells lie three to four deep. Within the inflammatory infiltrate lie prominent capillary vessels. (Haematoxylin and eosin, $\times 300$ ).

Fig. 1c

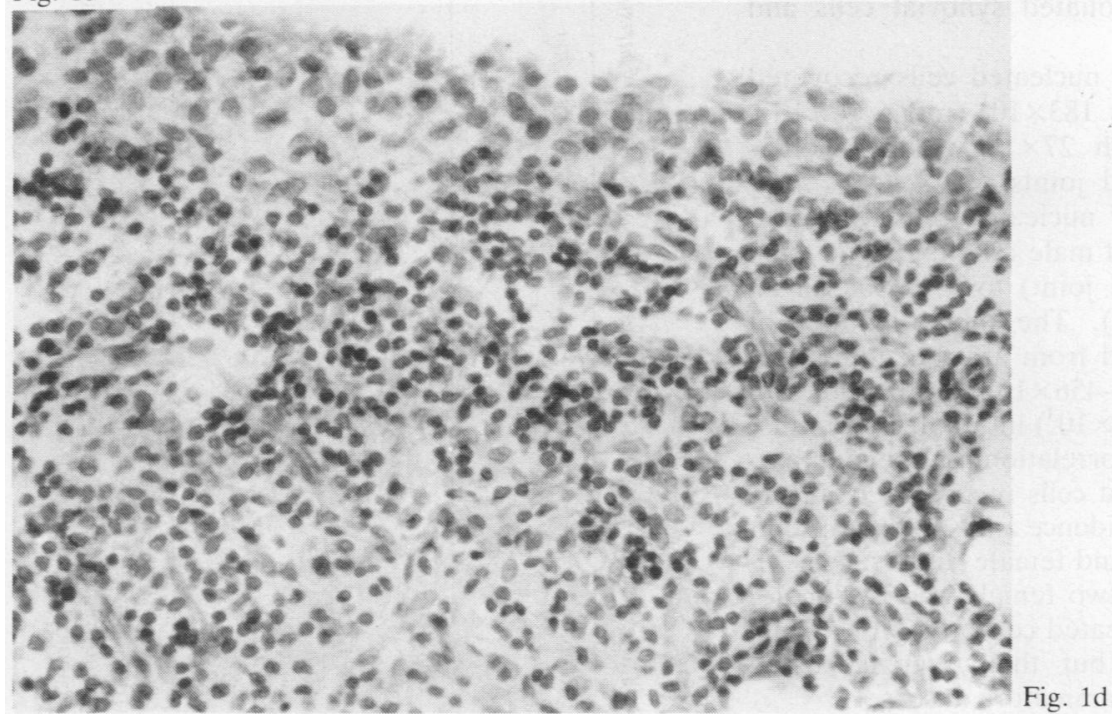


$(25 \%)$ of these rabbits. There was evidence of joint changes in $2 / 12(17 \%)$ male rabbits, though the changes in one of these rabbits (6835) were of marginal significance and present in one joint only.

DESCRIPTION OF JOINT LESIONS

A continuous spectrum of synovitis was observed, which was arbitrarily divided into mild, moderate, and severe categories (see Figs 1a-d), paying particular attention to those parameters used in headings in Table 2.

The mildest lesion (6835-a male rabbit) was detected in one knee only and consisted of only a very few lymphocytes and plasma cells beneath the surface and showed a perivascular distribution in places. With increasing severity of inflammation bilateral involvement became the rule, synoviocyte hyperplasia was more marked, and the density of chronic inflammatory cell infiltrate was greater, until the small focal lesions seen in less severely affected cases appeared to become confluent. Rheumatoid granulomas were not observed. There was no evidence whatsoever that this was an 'infective' arthritis, in the sense of a directly infected joint. The appearance of the lesions was consistent with an immunological event.

ANALYSIS OF CELLS RECOVERED FROM THE SYNOVIAL FLUID

Absolute numbers of nucleated cells

Females. The number of nucleated cells recovered from the synovial fluids of female rabbits ranged from $3 \times 10^{3}$ (in an unaffected joint) to $500 \times 10^{3}$ (from a joint with a lesion) (Fig. 2). We did not distinguish between exfoliated synovial cells and inflammatory cells.

The mean number of nucleated cells recovered from affected joints was $183 \times 10^{3}$ (range $16 \times 10^{3}$ $500 \times 10^{3}$ ) compared with $27 \times 10^{3}$ (range $3 \times 10^{3}-$ $90 \times 10^{3}$ ) from unaffected joints.

Males. The number of nucleated cells recovered from the synovial fluid of male rabbits ranged from $3 \times 10^{3}$ (in an unaffected joint) to $456 \times 10^{3}$ (in an inflamed joint) (Fig. 2). The mean number of nucleated cells recovered from affected joints was $230 \times 10^{3}$ (range $17 \times 10^{3}-456 \times 10^{3}$ ) compared with $18 \times 10^{3}$ (range $3 \times 10^{3}-48 \times 10^{3}$ ) in unaffected joints.

There was an overall correlation between increasing numbers of nucleated cells recovered from the synovial fluid and the incidence and severity of joint pathology in both male and female rabbits (Fig. 2). However, four rabbits (two female and two male) had raised levels of nucleated cells in their synovial fluids (i.e., $>40 \times 10^{3}$ ) but their synovial tissue showed no signs of inflammatory disease.

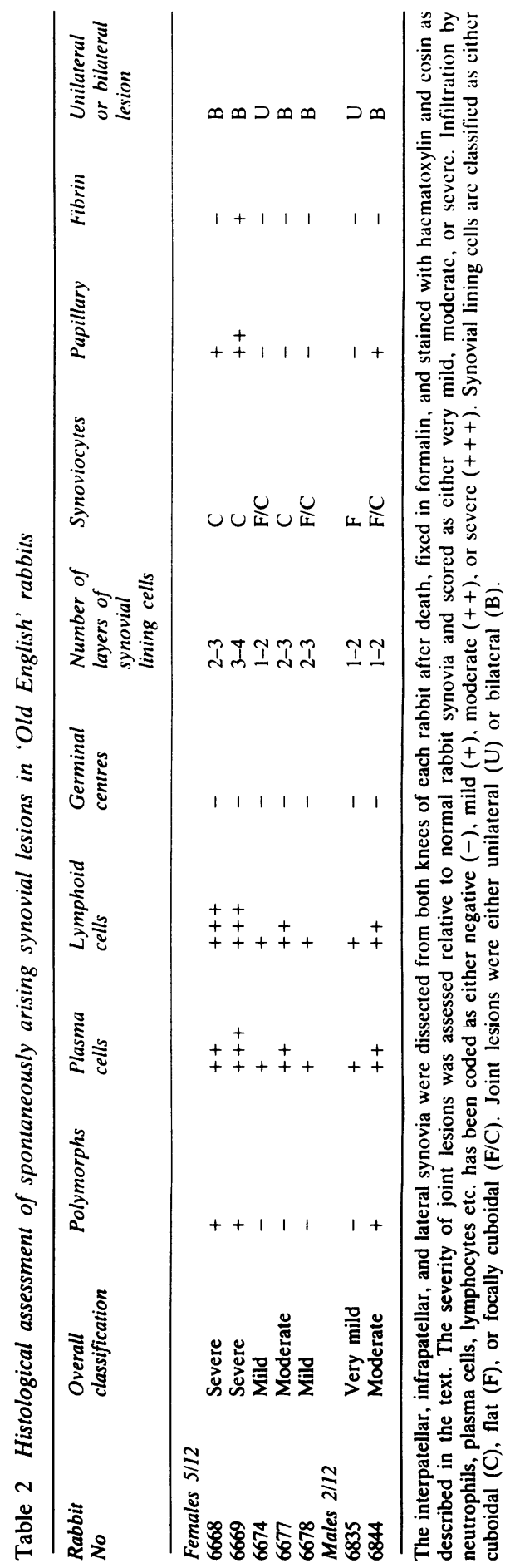




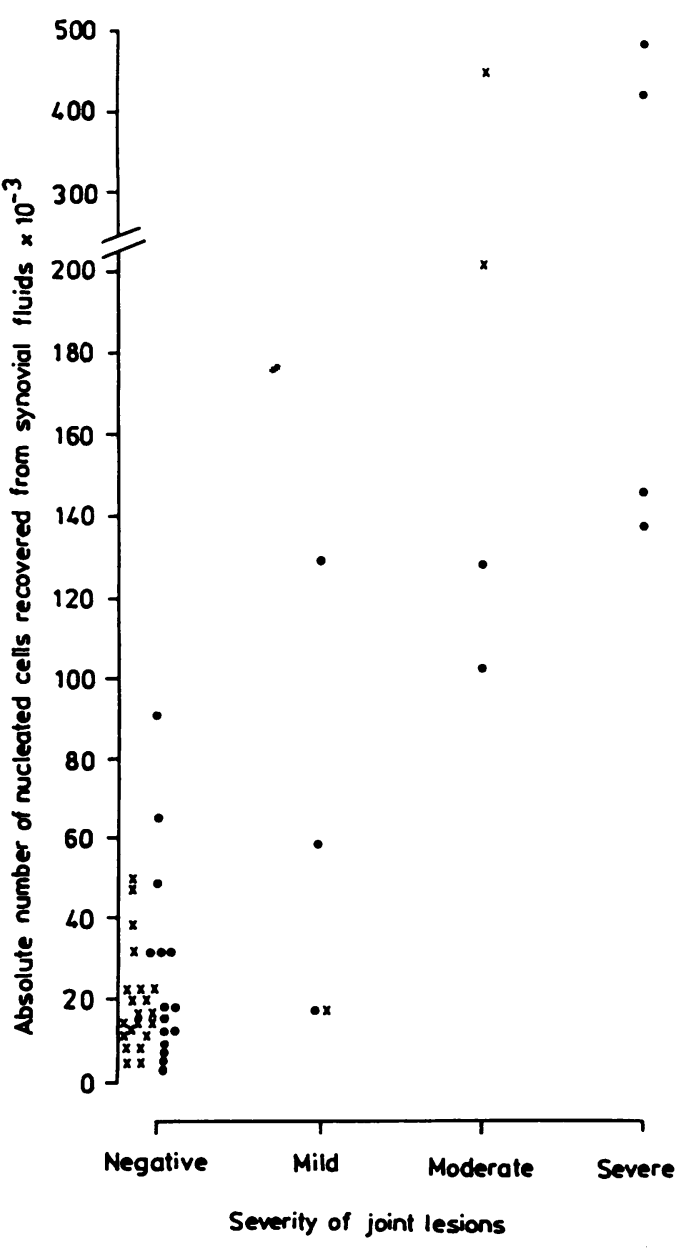

Fig. 2 Correlation between the increased number of nucleated cells recovered from the synovial fluids and the incidence and severity of spontaneous synovitis in 'Old English' rabbits. Nucleated cells were recovered from the synovial fluids of female (O) and male (X) 'Old English' rabbits after death (see 'Materials and methods').
T LYMPHOCYTES RECOVERED FROM SYNOVIAL FLUIDS OF RABBITS WITH JOINT PATHOLOGY

An overall increase in the percentage and absolute numbers of $T$ cells (Table 3 ) recovered from synovial fluids correlated with an increase in the incidence and severity of joint lesions in both male and female rabbits. The mean number $\pm S D$ of $T$ cells recovered from female rabbits with joint lesions was $60 \times 10^{3} \pm 73 \times 10^{3}$ (range $2 \times 10^{3}-$ $194 \times 10^{3}$ ) compared with $2 \times 10^{3} \pm 1 \times 10^{3}$ (range $<1 \times 10^{3}-4 \times 10^{3}$ ) in unaffected rabbits.

In male rabbits the mean number $\pm S D$ of $T$ cells recovered from affected rabbits was $107 \times 10^{3}$ $\pm 104 \times 10^{3}$ (range $3 \times 10^{3}-210 \times 10^{3}$ ) compared with $2 \times 10^{3} \pm 3 \times 10^{3}$ (range $<1 \times 10^{3}-13 \times 10^{3}$ ) in unaffected animals.

INCREASED TITRES OF SERUM IgM RF IN 'OLD ENGLISH' RABBITS

In the latter half of 1984 sera from five control female 'Old English' rabbits and seven control males were examined for IgM RF. Titres in all cases were $<4$. In the present investigation significant titres of IgM RF $(>8)$ were found in the sera of the majority of both male and female animals throughout the course of the experiment (see also Fig. 3). There was no relationship between serum IgM RF levels and the incidence and/or severity of joint pathology. In addition, there was no significant difference between serum IgM RF titres in male (mean $\pm \mathrm{SD}=$ $24 \pm 2$ ) and female (mean $\pm S D=23 \pm 2$ ) rabbits. IgM RF was not detected in synovial fluids at dilutions of $1: 10$.

C 1 q BINDING IMMUNE COMPLEXES

Raised levels of circulating immune complexes are a feature of rheumatoid arthritis in man. ${ }^{11}$ The sera of 'Old English' rabbits were therefore tested for the presence of $\mathrm{Clq}$ binding immune complexes. However, significant levels of $\mathrm{Clq}$ binding immune

Table 3 Absolute numbers of $T$ lymphocytes recovered from synovial fluids

\begin{tabular}{lllcc}
\hline Sex of rabbit & $\begin{array}{l}\text { Severity of joint } \\
\text { lesion }\end{array}$ & No of rabbits & $\begin{array}{l}\text { Mean \% of } T \\
\text { lymphocytes } \pm S D\end{array}$ & $\begin{array}{c}\text { Mean total of } T \\
\text { lymphocytes } \times 10^{-3} \pm S D\end{array}$ \\
\hline Femalc & Negative & 7 & $9 \pm 7$ & $2 \pm 1$ \\
& Mild & 2 & $19 \pm 10$ & $14 \pm 17$ \\
& Moderate & 1 & $24 \pm 1$ & $34 \pm 12$ \\
& Scverc & 2 & $27 \pm 16$ & $103 \pm 10$ \\
Malc & Negative & 10 & $7 \pm 7$ & $1 \pm 3$ \\
& Mild & 1 & $4 \pm 2$ & $16 \pm \pm 71$ \\
& Moderatc & 1 & $48 \pm 3$ & - \\
\hline
\end{tabular}


336 Hanglow, Welsh, Conn, Thomas, Coombs
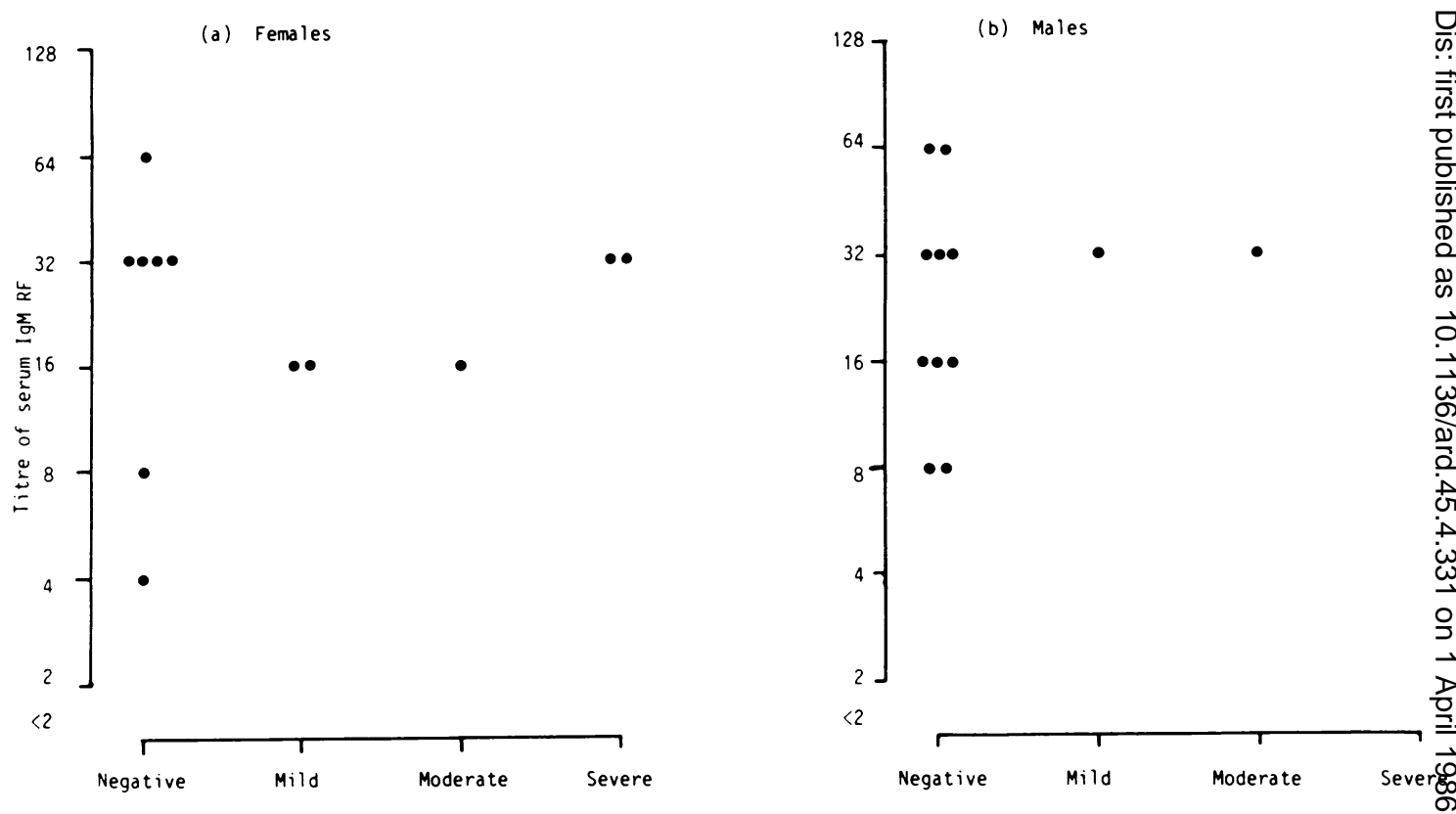

SEVERITY OF JOINT LESIONS

Fig. 3 Levels of IgM present in the postmortem serum of untreated 'Old English' rabbits. Serum IgM RF levels were measured in the postmortem sera from (a) female and $(b)$ male rabbits by their ability to bind to heat aggregated autologous IgG (as described in 'Materials and methods').

(a) FEMALES

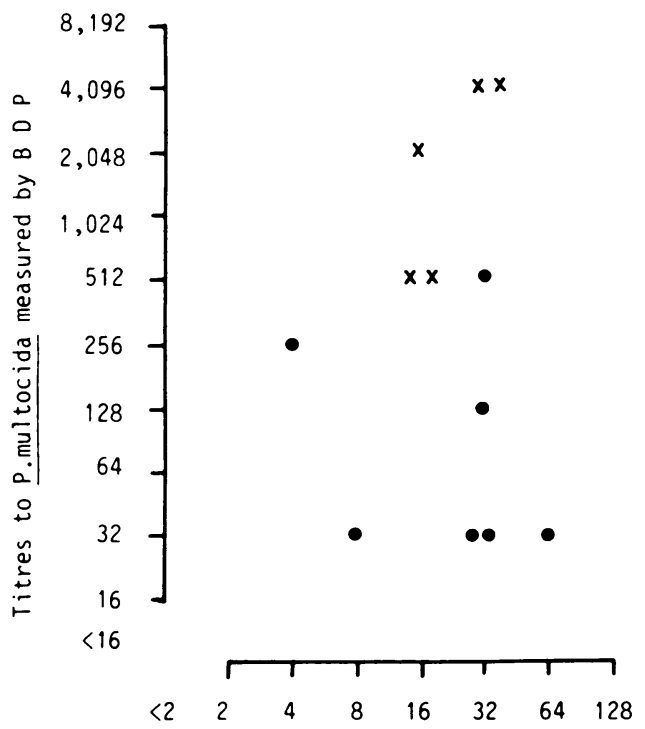

(b) MALES

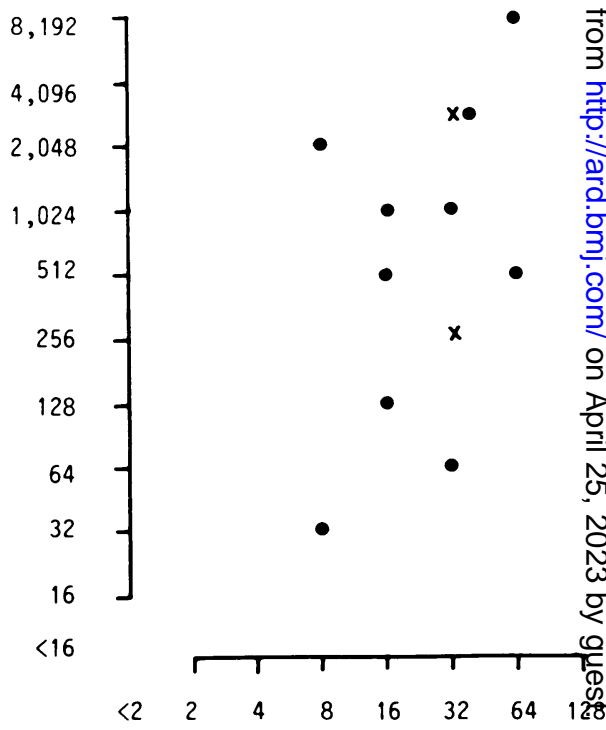

Titre of serum IgM RF

Fig. 4 Antibodies to P multocida detected in the postmortem sera of untreated 'Old English' rabbits. Antibody to $P$ multocida was measured in the postmortem sera of $(a)$ female and $(b)$ male 'Old English' rabbits by the MRPAH assay (see 'Materials and methods'). Results are expressed as titres measured by the bacterial dilution procedure (BDP). Rabbits ( with joint pathology $(X)$ and unaffected rabbits $(O)$ are shown. 
complexes were not detectable in either female or male 'Old English' rabbits (data not shown).

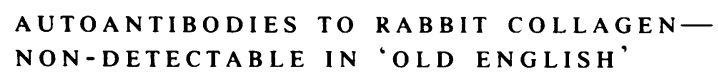

Autoantibodies to collagen have been reported in rheumatoid arthritis in man. ${ }^{12} 13$ The sera of 'Old English' rabbits were tested for the presence of such antibodies. However, significant binding to either type I or type II rabbit collagen was not observed in these animals (data not shown).

\section{MEASUREMENT OF SERUM $P$ multocida} $P$ multocida is a normal commensal in rabbits and is also responsible for many respiratory infections in these animals. In order to establish if $P$ multocida could be contributing to the development of IgM RF the postmortem sera of both male and female rabbits were tested for the presence of specific antibodies to this organism.

In female rabbits high titres of both serum IgM RF and antibody to $P$ multocida present concurrently were associated with the presence of synovitis (Fig. 4a). Although male rabbits showed equally high reactivity to $P$ multocida, there was no association with either serum IgM RF or the development of joint lesions (Fig. 4b).

\section{Discussion}

$42 \%(5 / 12)$ of female and $17 \%(2 / 12)$ of male rabbits of the 'Old English' breed tested in this experiment developed joint lesions spontaneously. These joint lesions were rheumatoid-like in nature being characterised by lymphocytic infiltration, plasma cells in the synovium, and increased numbers of $T$ lymphocytes in the synovial fluids of affected animals. Joint lesions were bilateral in most rabbits.

Joint pathology has now been observed in three out of 35 untreated control male rabbits used in all experiments, a cumulative incidence of $9 \%$ over a three year period. In comparison, synovitis has been observed in $10 / 31$ untreated female rabbits over the same three year period, representing a cumulative incidence of $32 \%$. This markedly higher incidence of joint lesions in females is also a feature of human rheumatoid arthritis where the prevalence is two to three times higher in females than males. ${ }^{14}$

Spontaneously arising rheumatoid-like lesions have been described in MRL/1 mice ${ }^{15}$ and in dogs. ${ }^{16}$ Although the MRL/1 mice develop high levels of both IgM and IgG RF, ${ }^{17}$ they also develop many pathological features unrelated to human rheumatoid arthritis (RA) but more characteristic of systemic lupus erythematosus and Sjögren's syndrome. ${ }^{18}$
They have a very short life span, develop glomerulonephritis leading to kidney failure, and also develop $\mathrm{T}$ cell lymphomas. A condition similar to RA is observed in dogs and is associated with serum IgM RF. ${ }^{19}$ 'Old English' rabbits develop a nonspecific synovitis consistent with RA and associated with the presence of IgM RF, a characteristic of RA in man. We have no evidence of extra-articular pathology in these animals. Raised serum levels of either $\mathrm{Clq}$ binding immune complexes or anticollagen antibodies, features of RA in humans, were not detected in untreated 'Old English' rabbits.

As stated previously, the incidence of spontaneous arthritis in 'Old English' rabbits has been increasing during the course of our experimental studies, particularly in female animals. The reason for this is not clear. Inbreeding of this particular rabbit (already known to be susceptible to development of experimentally induced arthritis) could have selected for animals with a genetic predisposition for the development of joint disease. Alternatively, the arthritis could have developed as a result of a microbial infection prevalent in the rabbit colony.

Untreated 'Old English' rabbits used in experiments before August 1984 did not show significant titres of serum IgM RF (i.e., <4). We have previously shown that these rabbits will develop joint lesions and serum IgM RF after intravenous injection of killed $E$ coli. ${ }^{2}$ This suggests that a bacterial infection could be responsible for the present 'spontaneously' occurring disease. $P$ multocida is a normal commensal in rabbits and may be one of many organisms contributing to the development of RF and possibly joint disease. Although both male and female rabbits used in the present experiments showed significant serum antibody levels to $P$ multocida, an association between this, serum IgM $\mathrm{RF}$, and joint disease was seen in female rabbits only. These results suggest that $P$ multocida may have been involved in the development of synovitis in these female 'Old English' rabbits.

We would like to thank Dr Anita Rampling (Public Health Services Laboratory. Addenbrooke's Hospital, Cambridge) for preparation of the $P$ multocida cultures. Dr M Barnes (Strangeways Research Laboratories. Cambridge) for the preparation of rabbit collagens. and Beverley Wilson for the histological preparations. We are especially grateful to Anita Hancock for her excellent secretarial assistance. This work was supported by the Arthritis and Rheumatism Council. UK.

\section{References}

1 Oldham G. Coombs R R A. Early rheumatoid-like joint lesions in rabbits injected with foreign serum or milk proteins. III. Influence of concomitant IgE-like antibodies and the breed of rabbit. Int Arch Allergy Appl Immunol 1980; 61: 81-90.

2 Hanglow A C. Welsh C J R. Conn P. Pitts J M. Rampling A. 
Coombs R R A. Experimental induction of rheumatoid factor and joint lesions after intravenous injections of killed bacteria. Ann Rheum Dis 1986; 45: 50-9.

3 Coombs R R A. Oldham G. Early rheumatoid-like joint lesions in rabbits drinking cows' milk. Int Arch Allergy Appl Immunol 1981; 64: 287-92.

4 Welsh C J R, Hanglow A C, Conn P. Barker T W H, Coombs R R A. Early rheumatoid-like synovial lesions in rabbits drinking cows' milk. I. Joint pathology. Int Arch Allergy Appl Immunol 1985; 78: 145-51.

5 Lee S K. Singh J. Taylor R B. Subclass of T cells with different sensitivities to cytotoxic antibody in the presence of anaesthetics. Eur J Immunol 1975: 5: 259-62.

6 Wilson A B. Gurner B W. Coombs R R A. Observations on rabbit thymocytes and peripheral $T$ cells. II. Rosette formation with rabbit erythrocytes. Int Arch Allergy Appl Immunol 1975: 48: 383-94.

7 Kelus A S, Gell P G H. Immunoglobulin allotypes of experimental animals. Progr Allerg 1967 11: 141-84.

8 Gosslau B. Barrach H-J. Enzyme linked immunosorbent microassay for quantification of specific antibodies to collagen type I. II. III. J Immunol Methods 1979: 29: 71-7.

9 Hanglow A C, Welsh C J R, Conn P. Coombs R R A. Early rheumatoid-like synovial lesions in rabbits drinking cows' milk. II. Antibody responses to bovine serum proteins. Int Arch Allergy Appl Immunol 1985; 78: 152-60.

10 Eggert F M. Edebo L B. Gurner B W. Coombs R R A. A simplified procedure for measuring the class of anti-bacterial antibodies by mixed reverse passive antiglobulin haemagglutination (MRPAH). J Immunol Methods 1979: 26: 125-40.

11 Zubler R H, Nydegger U E. Perrin LH, et al. Circulating and intra-articular immune complexes in patients with rhcumatoid arthritis. Correlation of ${ }^{125} \mathrm{I}-\mathrm{C} 1 \mathrm{q}$ binding activity with clinica $\mathrm{P}$ ? and biological features of the disease. J Clin Invest 1976: $57 \underset{\overrightarrow{7}}{\overrightarrow{7}}$ $1308-19$.

12 Steffen C. Timpl R. Antigenicity of collagen and its application in the serological investigations of rheumatoid arthritis sera. $\ln \bar{\sigma}$ Arch Allergy Appl Immunol 1963: 22: 333-49.

13 Michaeli D. Fudenberg $\mathrm{H} \mathrm{H}$. The incidence and antigenico specificity of antibodies against denatured human collagen in rheumatoid arthritis. Clin Immunol Immunopathol 1974: 2.્હ 153-9.

14 Hochberg M C. Adult and juvenile rheumatoid arthritis: current epidemiological concepts. Epidemiol Rev 1981: 3: $27-44$.

15 Hang L. Theofilopoulos A N. Dixon F J. A spontancousd rheumatoid-like disease in MRL/1 mice. J Exp Med 1982: 155:气 1690-701.

16 Newton C D. Lipowitz A J. Halliwell R E. Allen H L. Biery: D N. Schumacher H R. Rheumatoid arthritis in dogs. J Am Ver Med Assoc 1976: 168: 113-21.

17 Izui S. Eisenberg R A. Circulating anti-DNA rheumatoid factor complexes in MRL/1 mice. Clin Immunol Immunopathol 1980: 15: $536-51$.

18 Andrews B S. Eisenberg R A. Theofilopoulos A N. et al D Spontaneous murine lupus-like syndromes: clinical and immunopathological manifestations in several strains. J Exp Med 1978: 148: 1198-215.

19 Schumacher H R. Newton C. Halliwell R E W. Synoviafo pathological changes in spontaneous canine rheumatoid-like arthritis. Arthritis Rheum 1980: 23: 412-23. 